\title{
Koruma Sorumluluğu: Devletlerin Dünyasında İnsanları Korumak
}

\author{
Ali Onur Tepeciklioğlu ${ }^{1}$
}

Koruma Sorumluluğu: Devletlerin Dünyasında İnsanları Korumak

Öz

Bu çalışma, koruma sorumluluğunun sorunlu işleyişini kuramsal bir perspektifle analiz etmeyi amaçlamaktadır. ÇaIışma, İngiliz Okulu kuramından hareket ile insanların paylaştığı değer, kurum ve kurallarla, devletlerin paylaştığı değer kurum ve kurallar arasında bir çatışma olduğunu öne sürmektedir. İngiliz Okuluna göre devlet dışı aktörlerin paylaştığı değer ve kurallar ile bu değer ve kurallar üzerine kurulmuş kurumlar dünya toplumunun birer unsurudurlar. Koruma sorumluluğu da bu tanım doğrultusunda dünya toplumunun bir unsuru olarak tanımlanmıştır. Ancak koruma sorumluluğunun uygulanması uluslararası topluma bırakılmıştır. Uluslararası toplum da İngiliz Okulu tarafından devletler arasında paylaşılan değer ve kurallar ile bunların üzerine kurulmuş kurumların yarattığı düzeni ifade eder. Çalışma kapsamında, koruma sorumluluğunun sorunlu işleyişinin temel sebebinin uluslararası toplumun dünya toplumuna göre günümüz uluslararası ilişkilerinin örgütlenme biçimini belirleyecek kadar baskın konumda bulunması olduğu iddia edilmektedir.

Anahtar Kelimeler: Koruma Sorumluluğu, İngiliz Okulu, Uluslararası Toplum, Dünya Toplumu, İnsani Güvenlik
Responsibility to Protect: Protecting Humans in a World of States

Abstract

This study aims to analyze problems in Responsibility to Protect from a theoretical perspective. Drawing on the English School theory, it argues that rules and institutions shared by individuals are in conflict with the rules and institutions shared among states. For the English School, values and rules shared by individuals as well as institutions built on them are elements of world society. Based on this definition, Responsibility to Protect is defined as an element of world society. Nevertheless, international society is responsible for the implementation of Responsibility to Protect. The English School defines international society as a form of order which is established by the values, rules and institutions that are shared among states. International society prevails against world society in a way to determine the political organization of the contemporary international relations. This study further argues that this is also the principal reason behind the problematic functioning of the responsibility to protect.

Keywords: Responsibility to Protect, The English School, International Society, World Society, Human Security

\section{Giriş}

Bu makale, kuramsal bir perspektiften koruma sorumluluğu (Responsibility to Protect, R2P) mekanizmasının işleyişindeki sorunların sebeplerini tartışmayı amaçlamaktadır. Bu amaç doğrultusunda İngiliz Okulu kuramının uluslararası ilişkilerin politik örgütlenme biçimini tanımlayan üçlemesi, uluslararası sistem, uluslararası toplum ve dünya toplumu kavramlarından ve bunlar arasındaki ilişkiden yararlanılacaktır. Bu kavramlar arasındaki ayrım temel alınarak, koruma sorumluluğunun insanlar arasında paylaşılan ortak değer ve çıkarların oluşturduğu (Bull, 1985: 279) dünya toplumunun bir unsuru olduğu öne sürülmektedir. Bunun nedeni koruma sorumluluğu mekanizmasının dayandığı temel insan haklarının (Sue, 1980; Vincent, 1995: 123-126) herhangi bir ayrıma tabi olmaksızın tüm insanlar için geçerli olduğu prensibidir. Dünya toplumu kavramı da, insanlar arasında paylaşılan ve devletlerin sınırlarını aşan ortak çıkar ve değerleri ve bu değerlerin mobilize edilmesini tanımladığından, koruma sorumluluğunun özü uluslararası ilişkilerin dünya toplumu boyutuna dayanmaktadır.

Öte yandan, bu hakları pratikte korumak için oluşturulan koruma sorumluluğu mekanizması ise devletler arasında paylaşılan ortak değer, çıkar ve kurumların oluşturduğu (Bull, 1985: 14; Bull ve Watson, 1985: 1) uluslararası toplumun kurallarına göre işletilmektedir. Bu sadece bir

\footnotetext{
${ }^{1}$ Dr, Ege Üniversitesi İktisadi ve İdari Bilimler Fakültesi, Uluslararası İlişkiler Bölümü, ali.tepeciklioglu@ege.edu.tr, Yazar ORCID bilgisi: https://orcid.org/0000-0002-6135-1213
} 
tercih olmanın ötesinde bir zorunluluk olarak da değerlendirilebilir. Çünkü günümüz uluslararası ilişkilerinin politik örgütlenme biçimi üyelerinin ulus devletler olduğu bir uluslararası toplumdur. Dünya toplumunun bir unsuru olan koruma sorumluluğu ile koruma sorumluluğunun işleyişinin bağımlı olduğu günümüz uluslararası toplumunun temel dinamikleri özde çatışmaktadır. Çalışma, koruma sorumluluğunun işleyişindeki sorunların ve insani mezalimleri önlemede çoğu zaman yetersiz kalmasının sebebinin bu çatışmaya dayandığını iddia etmektedir.

Çalışmanın bu temel savı iki farklı şekilde daha ifade edilebilir. Birincisi, temel aktörleri ulus devletler olan günümüz uluslararası toplumunun kurumlarının ve doğasının, yeni olarak nitelenen ve doğrudan birey güvenliğine yönelen tehditlerle başa çıkmak amacıyla oluşturulmuş mekanizmaların temel prensibi olan kolektif hareket ve mutlak egemenlikten feragat ile özde çatıştığıdır. İkincisi, tehditlerin değişim hızıyla uluslararası ilişkilerin işleyiş prensiplerinin değişim hızı aynı değildir. Özellikle Soğuk Savaşın bitimiyle birlikte uluslararası ilişkilerde tehditler ve bu tehditlere karşı oluşturulan güvenlik mekanizmaları değişmektedir. Ancak uluslararası ilişkilerin temel prensipleri aynı kalmaktadır. Dolayısı ile uluslararası toplumun yapısı kökten değişmeden koruma sorumluluğu ve benzeri girişimlerin başarılı olma olasılıkları çok düşüktür. Her iki farklı ifade de temelde uluslararası ilişkilerin ne şekilde örgütlendiği ile yakından ilişkilidir. Günümüz uluslararası ilişkileri bir uluslararası toplum olarak örgütlenmektedir ve dünya toplumu unsurları çağdaş uluslararası toplumda sorunsuz işleyen kurumlar üretememektedirler.

Koruma sorumluluğu, hem Türkçe hem de uluslararası literatürde genellikle hukuki ve pratik açılardan incelenmektedir. Örneğin hukuki zeminde tartışanlar (Bellamy ve Reike, 2010; Arsava, 2011; Peltonen, 2011; Thakur, 2011; Telli, 2012; Gözen Ercan 2014), Birleşmiş Milletlerin kurucu prensibi olan içişlerine karışmama ve egemen eşitliği kavramları ile böyle bir mekanizmanın hukuki boyutunun ne ölçüde bağdaşabileceğini incelemektedirler. Uygulama zeminde tartışanlar(Mégret, 2009; Kenkel ve Stefan, 2016; Brockmeier vd., 2016) ise genelde egemenliğin dokunulmazlığı ile koruma sorumluluğu çerçevesinde öngörülen askeri müdahalenin bağdaşmazlığı konusuna eğilmektedirler. Buna ilaveten, mesele uygulamada yaşanan problemler açısından da incelenmektedir. Bu çalışmalar çoğunlukla koruma sorumluluğunun uygulanmasında ne gibi yanlışlar yapıldığı, örneğin uluslararası toplumun seçici davranması, mekanizmanın amacından saparak Batıya ait prensipler doğrultusunda zayıf ülkelerde rejim değişikliği aracı olarak kullanılması, askeri müdahaleye gerek duyulduğu takdirde kriterlerin nasıl objektif belirlenebileceği gibi çerçevelerde konuyu ele almaktadırlar (Hehir, 2013a; Thakur, 2013; Paris, 2014; Bellamy ve Dunne, 2016; Ertuğrul, 2016; Kelleci ve Ün, 2017; Hehir, 2019). Bu bağlamda, bu makale, çokça ele alınmış olan bu konuya kuramsal bir perspektifle yaklaşarak, tüm bu tartışmalara kuramsal zeminde bir katkı yapmayı hedeflemektedir.

Bu argüman/argümanları geliştirmek ve desteklemek amacıyla çalışma öncelikle İngiliz Okulu kuramının sunduğu kavramları ve kuramsal yaklaşımı kullanarak günümüz uluslararası ilişkilerinin işleyiş dinamiklerine yoğunlaşacaktır. Bu kısımda ulus devletin uluslararası alanın her boyutunda çok yüksek derecede belirleyici olması sebebiyle uluslararası toplumun devlet dışı ${ }^{2}$ uluslararası eylemi kısıtladığı iddia edilecektir. Bu bölümden sonra ise koruma sorumluluğu mekanizmasının dünya toplumu kavramı ile ilişkisi tartışılacak ve bu mekanizmanın nasıl çalıştığı

\footnotetext{
2 "Devlet dışı" her ne kadar günümüz uluslararası ilişkilerinde "ulus devlet harici” anlamına gelse de, burada kastedilen İngilizce ifadesi ile non-polity aktörlerdir. Türkçeye "yönetim dışı", "herhangi bir hükümet şeklinin dışında" olarak çevrilebilecek bu kavram yerleşik olmadığı için ifade edilmek isteneni tam olarak karşılamamasına rağmen devlet dışı ifadesi kullanılmıştır.
} 
ve hangi prensipler üzerine inşa edildiği analiz edilecektir. Bunu takiben çalışma, modern uluslararası ilişkilerin temel prensiplerinin koruma sorumluluğu mekanizmasının temel insan haklarını korumadaki yeterliliğini nasıl etkilediğine eğilecektir. Sonuç olarak koruma sorumluluğu ve benzeri girişimlerin dünya toplumuna ait unsurlar olarak devletlerin hâkim olduğu uluslararası toplumda radikal bir değişiklik olmadan insani mezalimleri önlemedeki başarılarının oldukça kısıtlı olacağını iddia edilmektedir.

\section{2. Çağdaş Uluslararası iliş̧kiler: Devletlerin Dünyası}

İngiliz Okulunun Uluslararası ilişkiler disiplinine katkısını ve kuramın ayrıntılarını tartışmak bu çalışmanın amacını fazlasıyla aşmaktadır. Ancak kuramın uluslararası ilişkilerin politik örgütlenme biçimini nasıl tanımladığı bu çalışma açısından önem arz etmektedir. Bunun başlıca nedeni kuramın, insan ve insanların paylaştığı değerler, çıkarlar ve kurumlar ile devlet ve devletlerin paylaştığı değerler, çıkarlar ve kurumları karşılaştırmada bir düzlem sunmasıdır. Uluslararası alanın tarih içerisinde belirli bir noktada hangi şekilde örgütlendiği uluslararası ilişkilerin temel dinamikleri üzerinde oldukça belirleyicidir. Bu sebeple imparatorluk, devletler sistemi, şehir devletleri sistemi ya da devletlerin arka planda olduğu bir yapı gibi çeşitli politik örgütlenme biçimlerinin uluslararası ilişkilerin yapılış biçimi üzerindeki etkisinin kuramsallaştırması bir analiz çerçevesi sunmaya adaydır. Örneğin, devletler arasında paylaşılan egemenliğinin dokunulmazlığı kuralı çerçevesinde işleyen uluslararası ilişkiler ile orta çağ Avrupası gibi insanlar arasında paylaşılan bir değer ${ }^{3}$ temelinde örgütlenen uluslararası ilişkilerin işleyiş şekilleri birbirlerinden oldukça farklı olacaktır.

Ingiliz Okulu kuramcılarının ortaya attığı yahut yeniden tanımladığı, ve İngiliz Okulu teorisinin üzerine oturduğu üç temel kavram bulunmaktadır. Bu kavramlardan birincisi olan uluslararası sistem, devletler arasındaki mekanik, ortak kurum ve kuralların işleyişine bağlı olmayan ancak her bir devletin eylemlerinde diğerlerini hesaba katmak mecburiyetinde bulunduğu bir politik yapıyı betimler (Bull, 1985: 14). Bir diğer ifade ile uluslararası sistem gönüllü birlikteliğe dayanmayan devletler arası ilişkileri tanımlar. Bir uluslararası sistemde devletler her hareketlerinde diğerlerini hesaba katarlar ancak ortak kural, kurum ve çıkarları paylaşmazlar.

Uluslararası toplum ise, uluslararası sistemin aksine, devletler arasında kural, kurum ve değerlerin paylaşıldığı, ortak çıkarlara hizmet eden birlikteliği tanımlayan bir kavramdır (Bull, 1985: 13; Bull ve Watson, 1985: 1). Her toplum gibi uluslararası toplumun da düzeni sağlamak, kendisini ve onu oluşturan elemanları korumak ve şiddeti minimize ederek barış ve refah ortamı sağlamak gibi amaçları vardır (Bull, 1985: 16-19). Uluslararası sistem, devletler arasındaki sosyal olmayan ilişkileri, yani devletlerin bir arada yaşarlarken herhangi bir müşterek kurum, değer ya da çıkar ile bağlı olmadıkları bir durumu tanımlarken, uluslararası toplum, devletler arasındaki sosyal ve müştereklik esasına dayanan ilişkileri tanımlamaktadır.

Uluslararası gerçekliğin bir diğer parçası olan dünya toplumu kavramı ise İngiliz Okulu tarafından uluslararası sistem ya da uluslararası toplum kadar net olarak tanımlanmamıştır. "Uluslararası toplumun altında yatan ve onun varlığını sağlayan insanların toplumu" (Manning, 1962: 177) şeklinde kabaca tanımlanan dünya toplumu, insanlar ve insan grupları arasında paylaşılan değer, kurum ve kurallar temelinde işleyen bir politik yapıyı ifade eder. Bull'a (1985: 279) göre dünya toplumu sadece dünyanın her bir yanındaki insanları birbirlerine bağlayan bir karşılıklı etkileşimden ibaret değildir. Aksine, insanlar arasındaki ortak çıkarlar ve değerler üzerine inşa edilebilecek ortak kurum ve kurallardır. Dünya toplumunun uluslararası sistem ve uluslararası

\footnotetext{
${ }^{3}$ Bu örnekte Hristiyanlık.
} 
topluma üstün geldiği zamanlarda devletlerin tamamen ortadan kalkması bir gereklilik değildir. İnsanlar arasında paylaşılan kurum ve kuralların uluslararası ilişkilerin işleyişini belirlediği hallerde farklı yönetim biçimleri varlıklarını sürdürebilirler. Önemli olan hangi kurum ve kuralların (devletlerin ya da insanların) uluslararası ilişkilerin yapılış biçimini belirlediğidir.

Bu noktada İngiliz Okulu kuramının uluslararası ilişkileri uluslararası sistem, uluslararası toplum ve dünya toplumunun daimi karşılıklı etkileşim içerisinde olduğu bir alan olarak (Bull, 1985: 41; Wight, 1991: 260) tanımlaması bu çalışmanın amaçlarına uygun analitik bir düzlem olarak değerlendirilmektedir. İngiliz Okulunun sunduğu bakış açısına göre, uluslararası gerçekliği bu üçlü politik örgütlenme biçimlerinin bir karışımı oluşturmaktadır. Bir diğer ifade ile insan grupları arasındaki yereli aşan ilişkiler, ya bu insan gruplarının benimsediği yönetim şekilleri (polity) arasında sistemik bir biçimde, ya yine bu yönetim şekilleri arasında toplumsal bir biçimde ya da bu yönetim şekillerinin ötesinde insan gruplarının oluşturduğu camia içerisinde cereyan edecektir. Bu üç ilişki biçiminin tamamı tarihin herhangi bir anında birlikte bulunmaktadır. Ancak bunlardan birisi uluslararası alanın temel prensiplerini belirleyecek ölçüde diğerlerinin önüne geçebilir (Bull, 1985: 52; Donelan, 1990; Wight, 1991: 260; Watson, 2002: 2-6;).

Uluslararası sistem, uluslararası toplum ve dünya toplumu birbirlerine tamamen dışlayıcı değildirler. Yani her birinden unsurlar eşzamanlı olarak uluslararası ilişkilerde bulunabilirler. Günümüz uluslararası ilişkilerinde olduğu gibi insanlar arasında paylaşılan değer, çıkar, kurum ve kurallar tamamen devletlerin dünyasından soyutlanmış değillerdir. Diğer taraftan bu üçlü arasındaki ilişki tamamen kapsayıcı da değildir. Örneğin, uluslararası toplum ile dünya toplumu arasında kurum ve değer bağlamında bir çatışma olduğu söylenebilir. İnsanların değerleri ve kurumlarının ön planda olduğu bir dünya toplumu ister istemez devletlerin kuralları ve değerlerinin uluslararası ilişkilere yön verdiği uluslararası toplum ile çatışacaktır. Çünkü insanlar arasında paylaşılan değer ve ortak çıkarlar üzerine kurulmuş bir uluslararası ilişkiler devletlerin varIığını anlamsız kılabilir ve uluslararası alanın politik örgütlenme biçimini kökten değiştirebilir. Yine bir uluslararası sistemde ortak çıkarlar çerçevesinde ortak kurum ve kuralların inşa edilmesi ve aktörler arasında toplumsallaşma, sistemsel baskılar nedeniyle kolay olmayacaktır.

Bu açıdan bakıldığında uluslararası ilişkiler ne realistlerin iddia ettiği gibi sadece bir uluslararası sistem, ne rasyonalistlerin öne sürdüğü gibi salt bir uluslararası toplum ne de idealistlerin savunduğu gibi bir dünya toplumu olarak tanımlanabilir. Uluslararası ilişkileri bu politik örgütlenme biçimlerinden birisine indirgemek, diğerlerinin uluslararası ilişkilerin temel dinamikleri üzerindeki etkilerinin göz ardı edilmesine yol açacaktır. Bu üç politik örgütlenme biçiminden biri diğerlerine dünya tarihindeki her hangi bir noktada baskın gelebilir. Ancak, örneğin 19. yy. Avrupası gibi devletlerin ve devletlerin kural, kurum ve çıkarlarının tam anlamıyla baskın olduğu bir uluslararası toplum olarak örgütlenmiş bir uluslararası ilişkiler bile, sistemik ve dünya toplumuna dair öğelerden tamamen yoksun değildir.

İngiliz Okulu kuramının bu üçlü yapısının uluslararası ilişkileri anlama/açıklama çabasına yaptığı katkıda kurumlar büyük önem taşımaktadır. Kurumlar, İngiliz okulunda Birleşmiş Milletler ya da Afrika Birliği gibi uluslararası örgütleri değil, aktörler arasında yapılageliş neticesinde oluşmuş davranış örüntülerini tanımlar. Bu örüntüler uluslararası alanda ortak amaçları gerçekleştirmede birer araçtırlar (Bull, 1985: 74). Bull'a göre günümüz uluslararası toplumunda, güçler dengesi, büyük güçler yönetimi, uluslararası hukuk, diplomasi ve savaş olmak üzere beş kurum bulunmaktadır. Bu kurumlar, uluslararası toplumda düzenin sağlanması ve devletler arasındaki ortak yaşamın amaçlarına ulaşılmasında araçsaldırlar. Yani uluslararası toplumun kurumları 
devletler arası ilişkiler ve yapılagelişlerden oluşmuş davranış örüntüleridir ve bu örüntüler uluslararası toplumda düzenin sağlanmasına katkıda bulunmaktadırlar.

Bu doğrultuda kurumların, yani uluslararası ilişkilerin işleyişinin, devletler arasındaki ilişkilerin oluşturduğu örüntüler ile mi yoksa insanlar arasındaki ilişkilerin oluşturduğu örüntüler ile mi belirlendiği oldukça önem arz eder. Bir başka ifade ile uluslararası ilişkilerin örgütlenme biçimi bir dünya toplumu ise, insanlar arasındaki ilişkilerin oluşturduğu örüntüler ya da kurumlar işleyişi belirleyebilir. Fakat uluslararası ilişkilerin örgütlenme biçimi bir uluslararası toplum ise devletlerin eylemleri neticesinde oluşmuş kurumlar bu işleyişi belirleyecektir. Bu kuramsal perspektif ile günümüz uluslararası ilişkilerini değerlendirdiğimizde, dünyanın politik yapısının üyelerinin ulus devletler olduğu bir uluslararası toplum olduğu öne sürülebilir. Bull (1985) tarafından anarşik toplum olarak tanımlanan bu yapı, herhangi bir üst otorite var olmadan ulus devletler arasında paylaşılan ortak değer ve çıkarlar temelinde kurulmuş ortak kurum ve kurallar çerçevesinde düzenli bir biçimde işlemektedir.

\section{Bir Dünya Toplumu Unsuru olarak Koruma Sorumluluğu}

Soğuk Savaşın bitimi ile birlikte uluslararası toplumda güvenlik anlayışının devleti güvenlik altına almaktan bireyi güvenlik altına almaya doğru değişmesi ile birlikte insani güvenlik kavramı literatürde önem kazanmaya başlamıştır. İnsani güvenlik kavramı basitçe güvenliğin referans aldığı objenin devletten bireye doğru değişmesi gerektiğini ifade etmektedir. Bir diğer ifade ile güvenlik sağlamak amacıyla alınan bütün önlemler ve atılan bütün adımlar devletleri değil bireyi hedef alan tehditlere odaklanmalıdır. Bu kavramsallaştırmaya göre "bireyi güvenlik altına almak, küreselleşmenin yarattığı tehditlerle yüz yüze gelen uluslararası toplumun sorunlarına eğilmenin en iyi yoludur" (Acharya, 2013: 449). İnsani güvenlik kavramı sadece askeri önlemler ile ele alınamayacak tehlikelerin tümünü kapsamaktadır. Bu kavramın ve bu kavramdan hareketle uygulanacak politikaların temel amacı bireyi şiddetten korumaktır (Hubert, 2004: 351). Ilaveten bu kavram, yeni uluslararası politik çevre tarafından üretilen tehditler ile mücadele etmekten uzak kalan dar güvenlik anlayışının üstesinden gelmeyi de amaçlamaktadır.

İnsani güvenlik kavramı sadece bir kavramsallaştırma değil aynı zamanda güvenlik politikalarının oluşturulması ve uygulanması ile de yakından ilişkili bir olgudur. Yani insani güvenlik sadece bir kavram olmaktan ziyade uluslararası güvenliğine yöneltilen yeni tehditlerin muhatabını ve bu tehditlerle başa çıkmak için yakın geçmişte oluşturulan mekanizmaları da kapsayan bir güvenlik anlayışıdır. Bir diğer biçimde ifade etmek gerekirse, insani güvenlik kavramı politika üzerinde de azımsanamayacak bir etkiye sahiptir. Anti-personel mayınların kullanımını, depolanmasını, üretilmesini ve taşınmasını yasaklama konvansiyonu, Birleşmiş Milletler barış koruma ve barış inşası operasyonları, Birleşmiş Milletler gelişme programları, Uluslararası Ceza Mahkemesi ve Dünya Sağıık Örgütü gibi devletten ziyade bireyi güvenlik altına almayı amaçlayan yeni mekanizmaların ve aktörlerin uluslararası sistem içerisinde geliştirilmeye başlanmasının sebebi bu etkidir. Bu mekanizmaların bireylere güvenlik sağlama amaçlarının yanı sıra bir başka ortak özelliği ise sınır aşan karakteristikleridir. Yani tüm bu mekanizmalar, bireyleri güvenlik altına almak için devletlerin kolektif olarak hareket etmelerini gerektirmektedir.

Insani güvenlik kavramı tanımı gereği modern devlet egemenliği anlayışını sorgulamaktadır. Bireye yöneltilmiş tehditlerin, belirli ve kesin devlet sınırları içerisinde ele alınması mümkün olmadığından, insani güvenlik uluslararası ilişkilerde devletlerin birlikte hareket etmelerini gerektirmektedir. Buna ek olarak devlet egemenliğinin ve toprak bütünlüğünün Soğuk Savaş sonrası dönemin karmaşık krizlerine göğüs germek için gerekli olan kapsayıcı mekanizmaların kurulma- 
sının önünde temel engel olduğu iddia edilebilir. Koşullu egemenlik kavramı, yani başka bir deyiş ile bir devletin belirli bir toprak parçası üzerinde meşru egemenlik haklarının kabul edilmesinin o devletin insan haklarına saygılı olması koşuluna bağlanması, bu gelişmelere paralel olarak koruma sorumluluğu gibi insani güvenlik mekanizmalarının temel yapı taşlarından birini oluşturmaktadır (Chandler, 2004: 65; Cunliffe, 2007: 48).

Klasik egemenlik anlayışı devletlerin uluslararası toplumun bir üyesi sayılabilmesi için diğer devletler tarafından tanınmayı uluslararası ilişkilerde bir arada var olmanın temel kuralı olarak belirlemektedir. Bu anlayışta önemli olan devletlerin birlikte var olmanın kurallarına uyup uymadıklarıdır, egemen oldukları toplum ve topraklar üzerinde nasıl tasarruflarda bulundukları uluslararası toplumun odak noktasında değildir. Dahası, uluslararası toplumun kolektif ya da üyelerinin bireysel olarak diğer devletlerin egemenlik alanları üzerinde tasarrufta bulunmaları düzeni bozma riski taşıdığı için uluslararası hukuka aykırı görülmüştür. Ancak sorumluluk olarak egemenlik anlayışı bu durumun tam tersine işaret etmektedir. Egemenliğin meşruiyetini diğer egemenler tarafından tanınmaktan çıkarıp kendi halkına ve uluslararası toplumun standartlarına karşı bir sorumluluk haline getiren bu anlayışa göre eğer devletler içişlerini uluslararası standartlara göre düzenlemezler ve kendi halklarına karşı olan sorumluluklarını önemsemezler ise, diğer devletlerin bu devlete müdahalesi sadece bir hak değil aynı zamanda bir görevdir (Deng vd., 2010). Wheeler'e (2000) göre insan haklarını ağır bir biçimde ihlal eden devletler meşru egemenlik haklarını kaybederler ve diğer devletlerin bu zulmü durdurmak için güç kullanmaları moral bir yükümlülüktür.

Ulus devletin egemenlik iddiasında bulunduğu ülke ve insanlar üzerinde her türlü mutlak hakkının olduğu klasik egemenlik anlayışı özellikle Soğuk Savaşın bitişi ile birlikte tartışmaya açılmıştır. İnsan haklarına saygı, demokrasi ve hukukun üstünlüğü gibi kriterler, bir devletin egemenlik hakkının belirli bir toprak parçası ve insan grubu üzerinde tanınabilmesi için gerekli koşullar olarak ortaya atılmıştır. Koruma sorumluluğu gibi insani güvenlik mekanizmaları da bu koşulları yerine getirmeyen devletler yerine insanları güvenlik altına almaya amaçladığından, klasik egemenlik anlayışı ile özde çatışmaktadırlar. Diğer bir ifade ile mutlak egemenlik ile koşullu egemenlik anlayışı arasında kaçınılmaz bir gerilim bulunmaktadır. Bu gerilimin temelinde, mutlak egemenlik anlayışının devletlere, uluslararası topluma ve düzenin korunmasına moral bir öncüllük verirken, sorumluluk olarak egemenlik anlayışının insanlara, dünya toplumuna ve adaletin sağlanmasına öncelik vermesi yatmaktadır (Bull, 1985; Wheeler, 2000).

Hem kavramsal olarak hem de pratik bir güvenlik uygulaması olarak ele alındığında insani güvenliğin doğrudan dünya toplumuna ait olduğunu söylemek doğru olmayacaktır. Çünkü insanın güvenlik altına alınması ile uluslararası ilişkilerdeki tehditlerin bertaraf edilmesi insanlar arasında paylaşılan bir değer ya da kural olarak tanımlanamaz. Ancak koruma sorumluluğu ve Uluslararası Ceza Mahkemesi gibi insani güvenlik mekanizmalarının temel aldığı yaşama ve iaşe hakkı gibi değerler insanlar arasında paylaşılan değerlerdir ve dolayısıyla bu mekanizmalar özde dünya toplumunun bir unsurudurlar. Bu nedenle insani güvenlik mekanizmaları her ne kadar devletler tarafından kurulmuş ve işletiliyor olsalar da onların dayandığı temel kural ve değerler insanlar arasında paylaşılmaktadır. Bu durum insan haklarının konumuna oldukça benzemektedir. İnsan hakları da İnsan Hakları Evrensel Beyannamesi ile devletler tarafından ilan edilmiş ve devletler hukukunun bir parçası haline gelmiştir. Ancak uluslararası hukukun bir parçası olması insan haklarının özde insanlar arasında paylaşılan değerleri temel aldığı gerçeğini değiştirmemektedir. 
Bu çalışmanın ana konusunu oluşturan "koruma sorumluluğu" ya da İngilizce literatürde bilinen adıyla "responsibility to protect" girişimi de bireyi güvenlik altına alma amacı yönünden yukarıdaki örnekler arasındadır (Okolo, 2008: 46-60). Koruma sorumluluğu günümüz uluslararası politikasında temel insan hakkı olan yaşama hakkına yöneltilmiş tehditler ile baş etmek amacıyla kurulduğundan, uluslararası toplum ve dünya toplumu arasındaki ilişki açısından büyük önem taşımaktadır. Son otuz yılda yaşanan mezalimlerin uluslararası kamuoyunda yarattığı büyük rahatsızlık neticesinde Birleşmiş Milletler tarafından soykırım, savaş suçları, etnik temizlik ve insanlığa karşı işlenen suçlardan toplumları korumak amacıyla 2005 Dünya Zirvesi Sonuç Belgesi vasıtasıyla (United Nations General Assembly, "2005 World Summit Outcome", A/RES/60/1) "Responsibility to Protect" yani koruma sorumluluğu olarak bilinen mekanizma oluşturulmuştur.

Koruma sorumluluğu insan haklarını güvence altına almanın standart devlet davranışı haline getirilmesi yolunda bir araçtır. Bu nedenle yukarıda sözü edilen koşullu egemenlik kavramıyla da yakinen ilişkilidir. Koruma sorumluluğu mekanizmasının ana amacı insani krizleri büyük mezalimlere dönüşmeden önce kontrol altına almak olarak kabaca tanımlanabilir. Bu kısa tanımdan da anlaşılabileceği üzere koruma sorumluluğunun da, diğer tüm insani güvenlik mekanizmalarında olduğu gibi, uygulanması devlet egemenliği ve bireyi güvenlik altına almak arasında bir gerilim ve çatışma yaratmaktadır. Başka bir ifade ile insanı güvenlik altına alma amacıyla kurulmuş bu mekanizma insanlar arasında paylaşılan ve dolayısıyla dünya toplumunun bir öğesi olan yaşam ve iaşe hakkına dayanmaktadır. Ancak bu kurumun işleyişinin prensipleri uluslararası toplumun kurumlarına bağımlıdır. Yani egemenlik haklarının kullanımı her ne kadar insan haklarına saygı gibi bir koşula bağlanmaya çalışılmış olsa da insani güvenlik mekanizmaları uluslararası toplum tarafından kontrol edilmektedir.

Koruma sorumluluğu mekanizması temelde üç sütun üzerine oturmaktadır (United Nations, Secretary-General Report, "Implementing the responsibility to protect", A/63/677, 2009). Buna göre halklarının soykırım, etnik temizlik ve bu gibi suçların kışkırtılmasına karşı korunmasından öncelikle devletlerin kendileri sorumludurlar. Başka bir ifade ile devletin kendi halkına karşı olan sorumluluğu, koruma sorumluluğunun ilk sütununu oluşturmaktadır. İkinci sütunu ise devletlerin bu gibi suçların gerçekleşmesinin önlenmesinde birbirlerine yardım etme ve uluslararası toplumun bu konuda devletleri destekleme sorumluluğu oluşturmaktadır. Koruma sorumluluğunun dayandığı üçüncü sütuna göre uluslararası toplum, devletlerin bu suçları önlemede etkisiz yahut isteksiz olmaları halinde, kararlı ve yerinde olmak üzere gerekli adımları atmak sorumluluğundadır (United Nations General Assembly Resolution, 2005 World Summit Outcome, A/Res/60/1, 2005: para. 138-140; United Nations Secretary General Report, Implementing the responsibility to protect, A/63/677, 2009: 10- 28; Bellamy, 2014: 7-8).

Özetle koruma sorumluluğu mekanizması, ilk düzlemde devletlere, ikinci ve üçüncü düzlemde ise hem bütün olarak devletlere hem de uluslararası topluma sorumluluk yüklemekte ve özellikle birinci sütunu ile insan haklarının korunması temelinde koşullu egemenlik vurgusu yapmaktadır. Ancak şu da unutulmamalıdır ki koruma sorumluluğunun tamamı ve özellikle birinci ve ikinci sütunda tanımlanan sorumluluklar, mezalimlerin önlenmesi için askeri olmayan - örneğin insan hakları ihlallerini izleme ve çeşitli insani yardımlar (Paris, 2014: 569-571) - tedbirleri de içermektedirler. Dolayısıyla "insani müdahale" kavramının içeriğinin aynı kalarak yerini "koruma sorumluluğu" kavramına bıraktığı iddiası oldukça tartışmalıdır. Aksine koruma sorumluluğu egemenliği yeniden tanımlamaktadır ve sorumluluk ile ilişkilendirmektedir. Dolayısıyla devletin başlıca sorumluluğu halkını korumasıdır (International Commission on Intervention 
and State Sovereignty, The Responsibility to Protect, A/57/303, 2001). Diğer bir ifade ile insani müdahale "hakkı" reddedilmekte, halkların korunması belirli kurallar çerçevesinde bir sorumluluk olarak tanımlanmaktadır.

Bu çerçevede koruma sorumluluğu, uluslararası toplumda temel insan haklarına saygı bağlamında norm inşa etme kapasitesi olan bir girişim olarak değerlendirilebilir (Gözen Ercan, 2014: 49-50). Ayrıca koruma sorumluluğu uluslararası topluma, insani krizler mezalimlere dönüşmeden önce müdahale edebilmek için yasal bir zemin de sunmaktadır. Ancak yasal zemin ve norm oluşturma potansiyeline rağmen koruma sorumluluğunun işletilmesi her olay için standardize edilmiş bir biçimde değildir. Başka bir deyişle koruma sorumluluğu mekanizmasının özellikle üçüncü sütununun işletilebilmesi için belirlenen kriterlerin başında "vaka bazında hareket etme" ${ }^{\prime 4}$ prensibi bulunmaktadır. Örneğin uluslararası toplum bir soykırım tehdidini ortadan kaldırmak için $A$ ülkesinde $X$ yılında harekete geçerken $B$ ülkesinde $Y$ yılında harekete geçmeyebilir. Dahası, üçüncü sütunun harekete geçirilmesinde, yani bir mezalime dönüşebilecek durumun ortadan kaldırılması için olayın yaşandığı topraklar üzerinde egemen olan devletin ve diğer devletlerin harekete geçmemesi halinde, uluslararası toplumun zamanında ve kesin sonuca ulaştıran eylemleri gerçekleştirilmesinde yetkili organ Birleşmiş Milletler Güvenlik Konseyi (BMGK) olarak belirlenmiştir (United Nations, 2005 World Summit Outcome Document, A/Res/60/1, 2005: para. 139).

\section{Dünya Toplumu ve Uluslararası Toplum Arasında Koruma Sorumluluğu}

Koruma sorumluluğu mekanizmasının hemen göze çarpan bu iki özelliğinin, yani vaka bazında çalışması ve yetkili organın BMGK olarak belirlenmesinin, uluslararası toplumda insani değerlere dayanan norm oluşturma kapasitesini baltaladığı söylenebilir. Vaka bazında hareket etme hem devletlerin hem de uluslararası toplumun tamamının seçici hareket etmesine zemin hazırlamaktadır. Koruma sorumluluğunun üçüncü sütununun, yani uluslararası topluma sorumluluk yükleyen ayağının işletilmesi, başka bir ifade ile uluslararası toplumun dünyanın herhangi bir yerindeki mezalime dönüşebilecek bir olayı önleme amacıyla harekete geçmesinin BMGK'ya bırakılması da önde gelen sorunlardan biridir. Bu hükmün anlamı uluslararası toplumdaki büyük güçlerin söz konusu olaylara müdahale edilip edilmeyeceğine karar vermesidir. Dahası BMGK oybirliğiyle aldığı kararlar ile değil, veto yetkisinin daimi üyelerce sıklıkla kullanılması ile bilinen bir organizasyondur. Bu resmin tamamı, koruma sorumluluğu mekanizmasının işlerliğinin büyük ölçüde devletler arasındaki ilişkilere bırakıldığını göstermektedir.

Sorunlu işleyişe yol açma potansiyeline sahip yapısıyla paralel olarak, koruma sorumluluğunun işlerliği hem uluslararası politikada hem de akademik yazında tartışma konusudur. Örneğin, kimi yazarlar, uluslararası toplumun sorumluluğunu yerine getirmesinin müdahale tartışmaları bağlamında yaratacağı sorunlardan hareketle, uluslararası toplumun rolünün mezalimler karşısında duran sivil toplum öğelerine yardım etmek ve destek vermekle kısıtlı olması gerektiğini savunmaktadırlar (Mégret, 2009: 591-593). Koruma sorumluluğu mekanizmasına getirilen bir

\footnotetext{
${ }^{4} 2005$ World Summit Outcome Document, A/Res/60/1, para. 139'daki ilgili hüküm şu şekildedir: “The international community, through the United Nations, also has the responsibility to use appropriate diplomatic, humanitarian and other peaceful means, in accordance with Chapters VI and VIII of the Charter, to help to protect populations from genocide, war crimes, ethnic cleansing and crimes against humanity. In this context, we are prepared to take collective action, in a timely and decisive manner, through the Security Council, in accordance with the Charter, including Chapter VII, on a case-by-case basis and in cooperation with relevant regional organizations as appropriate, should peaceful means be inadequate and national authorities are manifestly failing to protect their populations from genocide, war crimes, ethnic cleansing and crimes against humanity."
} 
diğer eleştiri ise bu mekanizmanın üçüncü sütununu her işletildiğinde yapısal sorunlarından ötürü kimi başarısızlıklara uğramasının kaçınılmaz olduğunu ileri sürmektedir. Paris (2014: 572580) bu yapısal sorunları, müdahaleye katılan devletlerin sadece insani müdahale amacıyla orada olmamaları, müdahalenin başarısının somut olarak ortaya konamaması, korunmaya çalışılan halkın da müdahaleden zarar görmesi, korumayı gerektiren koşulların yeniden oluşturulmadan müdahale eden unsurların nasıl geri çekileceği ve uluslararası toplumun sorumluluğa yaklaşımının tutarsız olması olarak sıralamaktadır.

Özellikle 2011 yılında 1973 sayılı Birleşmiş Milletler Güvenlik Konseyi kararı tavsiyesi neticesinde Libya'da işletilen koruma sorumluluğu birçok tartışmayı beraberinde getirmiştir. Bu tartışmaların temelinde uluslararası koalisyon tarafından sağlanan uçuşa yasak bölgenin Libya'da bir rejim değişikliğine yol açması ve bu durumun da koruma sorumluluğu üzerindeki şüpheleri arttırması yatmaktadır. Hatta bu durumun BMGK'nın Suriye, Yemen, Bahreyn ve benzeri krizlerde koruma sorumluluğunu işletme yönünde çıkmaza girmesine neden olduğu ve koruma sorumluluğu çerçevesinde askeri müdahalenin etkinliğini sorgulattığı da iddia edilmektedir (Brockmeier vd., 2016: 130-132). Benzer eleştiriler Libya krizinde koruma sorumluluğunu işleten güvenlik konseyinin daimi beş üyesinin insani mezalimler karşısında seçici/ayrımcı davrandıkları, yani bazı krizlere efektif ve yerinde müdahale ederken bazı krizleri görmezden geldikleri şeklinde de ifade edilmektedir. Uluslararası toplumun bu seçici/ayrımcı ve amaca özel tutumu BMGK'nın insani krizlerde tutarsız geçmişinin devamına yol açmaktadır (Hehir, 2013a: 137-159). Bunun yanı sıra Hehir (2013b: 51-52) BMGK üyelerinin pratikte bu kurumun gücünün sınırlarını da belirlemeye yetkili olduğunu; bu nedenle de uluslararası toplumda insani ihtiyaçlar söz konusu olduğunda bunun ancak üyelerin çıkarları ile örtüştüğü noktada karşılık bulabildiğini belirtmektedir.

BMGK ilk başta şekillendirilirken üyelerin kendi çıkarlarını hiyerarşik bir biçimde uluslararası toplumda koruması esasına göre oluşturulduğundan günümüz şartlarında bir reforma ihtiyaç duyulmaktadır. Ancak ilginç bir biçimde insani mezalimleri önlemeyi amaçlayan koruma sorumluluğu çıkar ve insani intiyaçlar dengesinde BMGK'ya kaçış yolu sunduğundan, BMGK üyelerinin bu reform ihtiyacını maskelemesine yol açmaktadır (Bellamy, 2009: 63). Bellamy ve Dunne'un da (2016: 265) belirttiği üzere BMGK'nın koruma sorumluluğu konusundaki çabaları uluslararası politikanın aşırılıklarından bağımsız ya da üzerinde değildir. Aksine, BMGK kurumsal olarak bu politik düzenin bir parçasıdır. Gözen Ercan da (2016: 114-138) BMGK'nın yapısının koruma sorumluluğunun işlerliği önünde bir engel oluşturduğunu kabul etmekte ve bu engelin aşılması için bir öneri getirmektedir. Bu öneriye göre veto engelinden kurtarılmış işler bir mekanizmanın hayata geçmesi için yetki BGMK'dan alınarak BM Genel Kurulu'na verilmelidir ve mekanizma kapsamında alınacak kararlarda BM Genel Sekreterinin de aktif rol oynaması gerekmektedir. Uluslararası ilişkilerin şiddete meyilli dünyasından insanlığı korumak için BMGK'nın yetersiz kaldığını iddia eden Roff (2013) bağımsız, ancak BM'ye karşı sorumlu ve zamanında gönüllü olarak harekete geçebilecek bir organın oluşturulması gerektiğini öne sürmektedir.

Kimi yazarlara göre koruma sorumluluğunun Libya sonrası geleceğinin nasıl şekilleneceğine Brezilya, Güney Afrika ve Hindistan gibi yükselişte olan ülkelerin de dahil edilerek karar verilmesi hem bu ülkelerin uluslararası toplumda liderlik vasıflarını yerine getirmeleri hem de Batı dünyasının uluslararası normlar konusunda konsensüs sağlaması açısından önem arz etmektedir (Thakur, 2013: 61-64). Nitekim Libya müdahalesinin koruma sorumluluğu üzerinde yarattığı olumsuz etki, Brezilya'nın "korurken sorumluluk" (responsbility while protecting) ismi verilen girişimi ile ortadan kaldırılmaya çalışılmıştır. Bu girişim temelde BMGK'nın hangi hallerde insani 
müdahaleye karar verebileceğinin bir standarda bağlanması ve müdahalenin uygulanması aşamasında izleme ve değerlendirme mekanizmaları kurulmasını önermekteydi. Ancak özellikle Brezilya'nın BMGK geçici üyeliği son bulduktan sonra bu girişim sonuçsuz kalmıştır (Kenkel ve Stefan, 2016: 51-53). Bu da günümüz uluslararası toplumun norm arzının halen geniş ölçüde büyük güçlerin elinde olduğunun bir göstergesi olarak değerlendirilebilir.

Şu ana kadar 12 BM Genel Kurulu, 71 de BMGK kararı ve BMGK başkanlık açıklaması koruma sorumluluğuna atıf yapmaktadır. ${ }^{5}$ Kararlar incelendiğinde genel kurul kararlarının tamamının BMGK başkanlık açıklamaları ve BMGK kararlarının 65'inin devletlerin kendi halklarına karşı olan sorumluluklarına vurgu yapan birinci sütuna atıf yapmakta olduğu görülebilir. ${ }^{6}$ Ancak birinci sütuna yapılan atıfların sayısının çokluğu, koruma sorumluluğunun birinci sütunun iyi işlemesi neticesinde BMGK tarafından sürekli olarak bu yolun seçilmesinden ötürü değildir. Aksine, birinci sütuna yapılan atıfların çok büyük bir çoğunluğu Suriye, Yemen, Orta Afrika Cumhuriyeti, Mali, Somali ve Sudan gibi insani mezalimlerin çözümsüzlük durumunda bulunduğu ve devletlerin kendi halklarına karşı olan koruma sorumluluklarını yerine getirmediği/getiremediği bölgelerdedir. Bilindiği üzere, özellikle Suriye gibi bölgelerdeki insan hakları ihlalleri ile etnik temizlik ve savaş suçlarının önlenememesinin başlıca sebeplerinden birisi uluslararası toplumun kolektif olarak harekete geçmemesidir. Dahası, bu eylemsizliğin sebebi yukarıda da değinildiği üzere Libya'da işletilen koruma sorumluluğu mekanizmasının Rusya ve Çin gibi ülkelerin tepkisini çekmesi ve bu ülkelerin BMGK'da koruma sorumluluğu bağlamında alınmaya çalışılan kararları sistematik biçimde veto etmeleridir.

Üçüncü sütunun işletilmesi, yani uluslararası toplumun dünya toplumuna ait bir değer bağlamında harekete geçmesi, ancak ve ancak yine o uluslararası toplumun güçler dengesi, büyük güçler yönetimi, diplomasi ve uluslararası hukuk gibi kurumlarının nasıl işlediğine bağlıdır. Libya'da güçler dengesi kurumu uluslararası toplumun bekasını koruma ve şiddeti azaltma bağlamında çalışırken ve büyük güçler bu amaç doğrultusunda hareket etmişlerken, Suriye'de süreç tamamıyla farklı işlemekte, güçler dengesi ve büyük güçler yönetimi nedeniyle koruma sorumluluğu işletilememektedir. Bu durum devletlerin dünyasının, dünya toplumunda paylaşılan değerler üzerine kurulmuş koruma sorumluluğu mekanizması gibi kurumların işlerliğini neredeyse tamamıyla kontrol ettiğine bir işarettir. Bir diğer deyişle, uluslararası toplum günümüz uluslararası ilişkilerinde dünya toplumuna baskın geldiği için insanlar arasında paylaşılan değerler üzerine inşa edilen bu mekanizma amaçlandığı gibi çalışmamaktadır.

Egemenliğin dokunulmazlığı ve müdahale etmeme prensibinin ciddi manada değiştiği, içerisinde yaşadığımız uluslararası toplumun insan hakları bağlamında duyarlılık geliştirdiği ve bunun bir norm olarak kabul edilmeye başlandığı uzun zamandır çeşitli yazarlar tarafından dile getirilmektedir (Linklater, 1981; Wheeler ve Dunne, 1998; Wheeler, 2000; Schermers, 2002;

\footnotetext{
$5 \mathrm{Bu}$ bilgi Global Centre for Responsiblity to Protect, "UN General Assembly Resolutions Referencing R2P", http://www.globalr2p.org/resources/1133; Global Centre for Responsiblity to Protect, "R2P References in United Nations Security Council Resolutions and Presidential Statements" http://www. globalr2p.org/media/files/unsc-resolutions-and-statements-with-r2p-table-as-of-20-june-2018.pdf (Erişim Tarihi 05/07/2018) adreslerinden derlenmiştir.

${ }^{6}$ Koruma sorumluluğunun ikinci ve üçüncü sütununa atıf yapılan toplam karar sayısı altıdır. Bunların ikisi - 08/12/2017 tarihli S/RES/2389 numaralı karar ile 31/03/2017 tarihli S/RES/2349 numaralı karar - Afrika'da büyük göller bölgesinde Boko Haram faaliyetlerine karşı bölge ülkelerine yapılan çağrıdır. Geriye kalan 05/12/2013 tarihli S/RES/2127 numaralı Orta Afrika Cumhuriyeti ile ilgili karar ikinci sütuna, 30/03/2011 tarihli S/RES/1975 numaralı Fildişi Sahilleri ile ilgili karar yine ikinci sütuna, 27/01/2006 tarihli S/RES/1653 numaralı Demokratik Kongo ve Burundi ile ilgili karar tüm bölge ülkelerine ve 26/02/2011 tarihli S/RES/1970 numaralı Libya ile ilgili karar ise tüm uluslararası topluma yani üçüncü sütuna atıf yapmaktadır.
} 
Mayall, 2013). Bu bağlamda oluşturulan ve egemenliğin sorumluluğa dayandığı görüşünü temel alan koruma sorumluluğun da bir norm haline geldiği ileri sürülmektedir. Örneğin Evans (2016) uluslararası toplumun BMGK eliyle bir konsensüs oluşturup harekete geçmekte sorunlar yaşamasına rağmen koruma sorumluluğunun günümüzde bir norm olarak yerleştiğini, çünkü hiçbir devlet yöneticisinin kendi sınırları dışında da olsa bir mezalime kayıtsız kalmayı düşünemeyeceğini belirtmektedir. Bellamy (2015: 182) ise artık dünyada koruma sorumluluğunun kabul edilip edilmemesinin tartışılmadığını, sadece nasıl uygulanacağının tartışıldığına vurgu yapmaktadır. Glanville (2015) de normların uluslararası ilişkilerde devlet davranışını belirlemede kilit öneme sahip olduğunu ve koruma sorumluluğunun bu bağlamda bir norm olarak yerleştiğini iddia etmektedir. Hatta devletlerin ve uluslararası toplumun yanı sıra, bireylerin koruma sorumluluğunun da tartışmaya açılması ve bu sorumluluğun benimsenmesi halinde yaşanan mezalimlerin bir kısmının azaltılacağı da öne sürülen bir görüştür (Hindawi, 2016).

Öte yandan, Brown ve Bohm (2015) ise bu sayılan kozmopolitan argümanlar ve benzerlerinin sadece krizlerin nasıl çözüleceğine çok dar bir bakış açısıyla fazlasıyla yoğunlaştığından, bu insani mezalimlere sebep olan yapısal faktörlerin göz ardı edilmesine yol açtığını iddia etmektedirler. Buna ilaveten, zaten var olan ekonomik ve sosyal müdahalelerin etnik anlaşmazlıkları ve çevresel etkenleri kötüleştirdiği bir dünyada koruma sorumluluğunun bu müdahalelere askeri bir boyut ekleyen "tehlikeli bir norm" olduğu da savunulmaktadır (Dunford ve Neu, 2019). Bir başka açıdan Hehir (2019: 8), koruma sorumluluğunun bir norm olarak uluslararası toplumda yayıldığını, ancak bunun insan haklarının devletler tarafından güvenceye alınmasının da yayılmasını sağlamadığını vurgulamaktadır. Bu temelde Hehir (2019: 8-15) koruma sorumluluğunu "içi boş" bir norm olarak tanımlamakta ve bunun esas nedeninin de uluslararası toplumun yönetim mekanizmalarında ihtiyaç duyulan reformların gerçekleştirilmemesi olduğunu dile getirmektedir.

Bu tartışmalar bağlamında bakıldığında uluslararası toplumda insanları korumanın bir norm ortaya çıkmasının, uluslararası toplumun devlet dışı aktör, kurum, kural ve değerlere doğrudan daha açık hale geleceği anlamına gelmediği öne sürülebilir. Uluslararası ilişkilerin temel işleyiş prensiplerine ve kurumlarına bakıldı̆̆ında devletler arasındaki uluslararası ilişkilerin, devlet dışı uluslararası ilişkilere hala çok yüksek derecede baskın olduğu değerlendirilmektedir. Bunun ana nedeni olarak yukarıda da tartışıldığı üzere, uluslararası toplum ile dünya toplumu arasındaki gerilim gösterilebilir. Bu sebeple, dünya toplumunun uluslararası toplumu aşan norm, kurum ve kural üretmesi en azından yakın gelecekte mümkün görünmemektedir. Yukarıda da alıntılandığı üzere mevcut literatür koruma sorumluluğunun bir norm olup olmadığını değil devlet davranışının bu norm etrafında şekillenip şekillenmediğini tartışmaktadır. Bu çalışma da devlet davranışının değişmediğinden hareketle dünya toplumu tarafından arz edilen bir normun uluslararası toplum tarafından benimsenmediğini vurgulamaktadır. Dolayısıyla, dünya toplumunun değerleri üzerine kurulmuş koruma sorumluluğu mekanizmasının sorunsuz işlemesi, günümüz uluslararası toplumunun uluslararası alanı devlet dışı hemen hemen her şeye sınırlaması nedeniyle oldukça düşük bir olasılık olarak görülebilir.

\section{Sonuç}

Wight'a (1978: 111) göre her uluslararası toplumun kurumları o uluslararası toplumun doğasına göre şekillenir. Her ne kadar Wight uluslararası toplumun doğasının ne olduğunu açıkça belirtmese de, uluslararası toplum ve kurumları üzerine yapılmış birçok çalışmadan uluslararası toplumun doğasının ya da başka bir ifade ile kurucu prensibinin geri kalan tüm kurumların çaIışma ve işleyişini belirlediğini çıkarabiliriz (Buzan, 2004: 184; Schouenborg, 2012). Yani Wight, 
uluslararası toplumun doğası ile uluslararası ilişkilerin kurucu prensibinin diğer bütün kurumların işleyişi üzerinde belirleyici olduğunu belirtmektedir. Örneğin, ortaçağda Avrupa uluslararası toplumunun kurucu prensibi olan feodal sistem, aynı toprak parçası üzerinde birden çok yasal egemenlik hakkına olanak tanıdığı için bu uluslararası toplumda mutlak ve geçirgen olmayan sınırlar, egemenliğin dokunulmazlığı, güçlü merkezi otorite, devlet temelli uluslararası hukuk gibi kurumlar bulunmamaktaydı.

Günümüz uluslararası toplumunun kurucu prensibi veyahut esas kurumu ise karşılıklı olarak dışlayıcılık prensibine dayalı egemenliktir. ${ }^{7}$ Günümüz uluslararası toplumunda egemen ulus devletlerin, sınırları kesin bir biçimde belirlenmiş toprak parçaları üzerinde, teoride hiç kimse ve hiçbir kurum ile paylaşmadıkları, nihai otoriteleri vardır. Her uluslararası toplumun kurumlarının onun "doğası" çerçevesinde şekillendiğinden hareketle, içerisinde yaşadığımız ve tüm küreye nüfuz eden uluslararası toplumun hem kurumları, hem de temel işleyiş prensiplerinin modern egemenlik anlayışına göre şekillendiğini söyleyebiliriz. Bu nedenle, günümüz uluslararası ilişkilerinde ulus devlet dışında bir aktörün, ulus devletler tarafından üretilmeyen bir kurumun veya ulus devletlerin eylemleri sonucunda kabul görmemiş bir normun belirleyici olma olasıllı̆ı çok düşüktür.

Modern egemenlik anlayışının uluslararası hukukta da vücut bulan müdahale etmeme prensibinin ötesinde, uluslararası ilişkileri kapatma/sınırlama olarak adlandırılabilecek bir etkisinden söz etmek mümkündür. Modern, dışlayıcı ve eşit egemenlik anlayışı uluslararası ilişkileri sadece ve sadece bu özelliğe haiz ulus devletlerin alanı olarak belirlemektedir. Oysa uluslararası ilişkiler büyük insan gruplarının bir arada yaşama sorunsalıdır ve Uluslararası ilişkiler Disiplini de bu sorunsala yanıt arayan akademik çabayı tanımlamaktadır. Dolayısıyla bu insan toplulukları ulus devletler biçiminde örgütlenebilecekleri gibi imparatorluklar, şehir devletleri ya da çok daha kapsayıcı medeniyet bazlı, din bazlı veya tüm insanlığın ortak değerleri bazlı politik yapılar halinde de örgütlenebilirler. Bu açıdan bakıldığında, modern egemenlik anlayışının ve dolayısıyla ulus devletin uluslararası ilişkiler üzerindeki en önemli etkisi devlet dışındaki herhangi bir politik örgütlenme biçimine çok sınırlı hareket alanı bırakmasıdır.

Modern egemenlik anlayışı uluslararası alanın sınırlanmasını hem coğrafi, hem de coğrafyadan bağımsız olarak gerçekleştirmektedir. Öncelikle günümüz dünyasına baktı̆̆ımız zaman kâğıt üzerinde ulus devlet tarafından yönetilmeyen tek bir kara parçası bile bulunmamaktadır. Dünya üzerinde ulus devlet bir yönetim biçimi olarak oldukça baskın konumdadır. Bu da fiziki anlamda tüm uluslararası ilişkileri ulus devletler arasındaki ilişkiler yapmaktadır. Buna paralel olarak ulus devlet sadece kendi sınırları dâhilindeki alanı çok güçlü ve merkezi biçimde kontrol etmez, aynı zamanda diğer ulus devletlerle ilişkilerinin neticesi olarak ortaya çıkan norm ve kurumlarla uluslararası alanı da ulus devlet dışındaki tüm aktör ve değerlere kapatır. Dolayısıyla devlet dışında ${ }^{8}$ oluşmuş olan tüm norm ve kurumlar ya uluslararası alanın haricinde kalmaktadır ya da devlet eliyle uluslararasılaştırılmaktadır.

\footnotetext{
7 İngilizce ifadesi ile "mutually exclusive sovereignty".

8 İngilizce ifadesi ile "non-polity". Şu da belirtilmelidir ki, "polity" ve "non-polity" ifadeleri İngilizce literatürde de yaygın olarak kullanılmamaktadır. Bu ifadelerin yerine Türkçe'de "devlet" ve "devlet dışı" olarak çevrilebilecek "state" ve "nonstate" kavramları, belirli bir insan topluluğunun ortaklaşa bir yönetim biçimini benimsediği ve benimsemediği durumları nitelemek için kullanılmaktadır. Ancak "devlet" ve "devlet dışı" ifadeleri gibi "state" ve "non-state" ifadeleri de ulus devlete güçlü referanslar verdiği ve ulus devlet dışındaki yönetim biçimlerini dışladığı için "polity"|"non-polity" kullanımının anlatılmak isteneni daha iyi karşılayan ifadeler olduğu öne sürülebilir.
} 
Bu nedenle bugün, insan haklarına saygı, dini bağlılık, medeniyet gibi kapsayıcı kimlikler, uluslararası ceza mahkemeleri ve benzeri kurumlar, insanlar tarafından paylaşılan birçok müşterek değer üzerinde konumlanan norm ve kurum uluslararası alana ya devletler tarafından taşınmaktadır ya da uluslararası ilişkilerin dışarısında kalmaktadır. Özetle günümüz uluslararası ilişkileri devletlerin dünyasıdır. İster devlet kaynaklı ister birey kaynaklı olsun, yereli aşan tüm eylem, kural, kurum, düşünce, değer ve kimlikler üyeleri ulus devletler olan günümüz uluslararası toplumunda hareket etmektedirler.

Uluslararası alanın politik örgütlenme biçimi, bir diğer ifade ile dünya üzerindeki insanların ve toprakların nasıl gruplandıkları, uluslararası ilişkilerin hem genel işleyiş̧ini hem de bu genel işleyiş içerisindeki belirli olayların gerçekleşme biçimini anlamada bir analiz düzlemi sunmaktadır. Bu çalışma da, günümüz uluslararası ilişkilerinin politik örgütlenme biçimini analiz ederek, bu politik örgütlenme biçiminin belirli bir olgu üzerindeki etkilerini açıklamaya çalışmıştır. Koruma sorumluluğunu bu çerçeveden ele aldığımızda, günümüz uluslararası ilişkilerinin ulus devletlerin oldukça baskın olduğu bir uluslararası toplum olması, bu mekanizmanın amacına uygun biçimde insani mezalimleri önlemede yetersiz kalmasının başlıca nedenlerinden birisi olarak değerlendirilmiştir. Her ne kadar devlet dışı aktörler ve uluslararası örgütler, özellikle insanların yaşam haklarının korunması gibi kritik konularda etkinliklerini gün geçtikçe arttırsalar da uluslararası alanın temel politik örgütlenme biçimi halen büyük ölçüde ulus devletler tarafından belirlenmektedir. Koruma sorumluluğu mekanizmasının dayandığı değer temel insan haklarının korunmasıdır. Bu biçimde şekillenen bir uluslararası alanda, insan haklarının korunmasının dünya toplumuna ait bir değer olmasından hareketle, yani insanlar arasında paylaşılan bir değer olmasından mütevellit, uluslararası toplum tarafından norm olarak benimsenmesi ve devlet davranışının tamamıyla bu norm etrafında şekillenmesi oldukça güç görünmektedir. Çünkü içerisinde yaşadığımız uluslararası toplum, hem uluslararası hem de yerel alanın neredeyse tamamen ulus devletler tarafından kontrol edildiği bir politik yapı arz etmektedir ve bu politik yapı devlet dışı aktörlerce yaratılmış neredeyse tüm kural, kurum, değer ve normlara çoğu zaman kapalıdır.

Koruma sorumluluğu mekanizmasının devlet egemenliğinin dokunulmazlığı prensibiyle özde çatışması sebebi ile işleyişinin sorunlu olması da yine temelde dünya toplumu ile uluslararası toplum arasındaki ilişkiye dayanmaktadır. Ulus devletlerin egemenlik hakkı yahut egemenliğin dokunulmazlığı, uluslararası toplumun temel kurumlarından olan uluslararası hukuk tarafından güvenceye alınmıştır. Diğer bir ifade ile devletler arasındaki pratikler egemenliği ulus devletin bir hakkı ve dokunulmaz bir alan olarak tanımlamaktadırlar. Yani egemenliğin dokunulmazlığı uluslararası topluma ait ortak bir kurum, hatta günümüz uluslararası toplumunun kurucu prensibidir. Bu açıdan bakıldığında temel insan haklarının korunmasına dayanan koruma sorumluluğu mekanizması da uluslararası hukuk tarafından güvence altına alınmıştır. Ancak aradaki temel fark bu mekanizmanın özde bu çalışmada çerçevesi çizilmeye çalışılan dünya toplumunun bir unsuru olmasıdır. Herhangi bir ayrıma dayanmadan tüm insanlığa uygulanması gereken, yani özünde sınır aşan ve insanlar arasında paylaşılan bir değer üzerine kurulmuş bir kurumdur. Dünya toplumunun bu anlamda üstün geldiği bir uluslararası ilişkiler, uluslararası toplumu, yani uluslararası ilişkilerin parçalı yapısını ortadan kaldırmaya yahut geri plana itmeye adaydır. Bu nedenle, dünya toplumu ile günümüz uluslararası toplumu arasında bir gerilim bulunmaktadır. Bu da koruma sorumluluğu mekanizmasının devletlerin dünyasında sorunsuz bir biçimde işleyememesine ve insani mezalimleri amaçlandığı üzere önleyememesine yol açmaktadır. 
Bireyi güvenlik altına almaya çalışan koruma sorumluluğu gibi mekanizmaların bu sorunları önlemede yetersiz kalmaya devam etmelerinin sebeplerinden bir başkası olan değişimin aynı hızda olmaması da yine dünya toplumu ve uluslararası toplum arasındaki gerilim ile açıklanabilir. Soğuk Savaşın bitimi ile uluslararası politikada yaşanan soru ve sorunlardaki değişim uluslararası ilişkilerin kurucu prensiplerine yansımamıştır. Yani politik düzlemde ortaya çıkan güvenlik anlayışının her ne kadar bireyi referans alan bir yapısı olsa da, uluslararası ilişkiler ulus devlet ve ulus devletlerin oluşturduğu kurumlar tarafından belirlenmektedir.

Özetle bu durumda ulaşıması amaçlanan hedef ile uygulama arasında bir uyumsuzluk bulunmaktadır. Koruma sorumluluğu gibi mekanizma ve girişimlerde hedef bireyi koruma altına almak iken bu girişimlerin uygulanma yöntemi ziyadesiyle devlet merkezli olmaya devam etmektedir. Bireyi güvenlik altına almak Soğuk Savaştan sonra ortaya çıkan tehditlerle başa çıkmak üzere geliştirilen en iyi yöntemlerden biri olarak sayılabilir, ancak bireyi güvenlik altına almak üzere üretilmiş yeni güvenlik mekanizmaları uluslararası ilişkilerin bu gibi girişimlere uygun zemini sağlamamasından ötürü büyük ölçüde sorunlarla karşılaşmaktadırlar. Soğuk Savaşın bitimi uluslararası sistemin ürettiği politikalarda önemli ve çeşitli değişikliklere sebep olmuş olabilir, ancak uluslararası ilişkilerin politik örgütlenme biçimi bu değişimlerden biri değildir. Soğuk Savaş bittikten sonra, tıpkı Soğuk Savaş yıllarında ve öncesinde olduğu gibi, uluslararası sistem ekseriyetle birbirini karşılıklı olarak dışlayan egemenlik prensibine göre işlemektedir. Uluslararası toplumun temel kurum, kural ve ortak çıkarları ile dünya toplumunda insanlar arasında paylaşılan insan hakları gibi değerlerin bağdaşmasında pratikte yaşanan zorlukların ana sebebi olarak bu durum gösterilebilir. Odak noktasına insani güvenliği alan koruma sorumluluğu ve benzeri mekanizmaların işleyebilmesi için 1990 'lı yıllardan sonra ortaya çıkan yeni uluslararası politik çevrede klasik devlet egemenliği anlayışının ve uygulamalarının kaçınılmaz olarak değişime uğraması gerekmektedir.

Bu değişimin gerekliliği için üç ana neden öne sürülebilir. Bunlardan birincisi devletlerin bizzat kendilerinin birey güvenliğine yönelebilecek en önemli tehditlerden olma potansiyeli taşımalarıdır. İkincisi, yeni tehditlerin neredeyse tamamının sınır aşan tehditler olmalarıdır. Üçüncü neden ise, ikinciyle bağlantılı olarak, bu tehditlerle başa çıkmak için üretilen neredeyse tüm mekanizmaların, sınır aşan işbirlikleri ve kolektif hareket gerektirmesidir. Bir başka deyişle, bu mekanizmaların dayandıkları değerler dünya toplumunun unsurlarıdırlar. Öte yandan modern uluslararası toplum ve kurumları ise karşılıklı dışlayıcı egemenlik prensibi üzerine kurulmuştur. Bu sebeple, bir hükümetin kendi toprakları ve halkı üzerinde mutlak ve sorgulanamaz otoritesine karşılık gelen klasik egemenlik nosyonu insani güvenlik kavramı ve olgusu ile bağdaşmaz bir noktadadır. İnsani güvenlik kavramı ve bu kavramı baz alarak kurulmuş mekanizmalar ister istemez klasik egemenlik anlayışını sorgulamaktadır. Bir diğer ifade ile oyunun kuralları değişmezken oyunun doğası değişmektedir. Yani Soğuk Savaşın bitimi ile gerçekleşen değişim uluslararası sistemin kurucu prensiplerinde değil genel güç dağılımındadır (Waltz, 2000: 39). Özetle, kuramsal bir perspektiften bakıldı̆̆ında soykırım, savaş suçları, etnik temizlik ve insanlığa karşı işlenen suçları önlemek amacıyla kurulan koruma sorumluluğu ve benzeri mekanizmalar ile ilgili olarak sıklıkla dile getirilen sorunların sebebi, devletlerin dünyasında insanların değerlerinin korunmasındaki güçlüktür. 


\section{Kaynaklar}

Acharya, Amitav (2013), "Human Security”, (Ed. John Baylis vd.), The Globalization in World Politics, Oxford: Oxford University Press: 448-463.

Arsava, A.Füsun (2011), "Egemenlik ve Koruma Sorumluluğu”, Gazi Üniversitesi Hukuk Fakültesi Dergisi, C. 15, S. 1: 101124.

Bellamy, Alex (2009), Responsibility to Protect: The Global Effort to End Mass Atrocities, Londra: Polity.

Bellamy, Alex (2015), "The Responsibility to Protect Turns Ten”, Ethics \& International Affairs, C. 29, S. 2: 161-185.

Bellamy, Alex; Dunne, Tim (2016), "UN Security Council”, The Oxford Handbook of the Responsibility to Protect, (Ed. Alex Bellamy ve Tim Dunne), Oxford: Oxford University Press: 249-265.

Bellamy, Alex; Reike, Ruben (2010), "The responsibility to protect and international law", Global Responsibility to Protect, C. 2, S. 3: 267-286.

Brockmeier, Sarah, Stuenkel, Oliver, Tourinho, Marcos (2016), "The impact of the Libya intervention debates on norms of protection", Global Society, C. 30, S.1: 113-133.

Brown, Garrett Wallace; Bohm, Alexandra (2016), "Introducing Jus ante Bellum as a cosmopolitan approach to humanitarian intervention”, European Journal of International Relations, C. 22, S. 4: 897-919.

Bull, Hedley (1985), The Anarchical Society: A Study of Order in World Politics, Hong Kong: Macmillan.

Bull, Hedley; Watson, Adam (1985), "Introduction", (Ed. Hedley Bull ve Adam Watson), The Expansion of International Society, Oxford: Clarendon Press: 1-9.

Buzan, Barry (2004), From International to World Society? English School Theory and the Social Structure of Globalisation, Cambridge: Cambridge University Press.

Chandler, David (2004), "The Responsibility to Protect? Imposing the 'Liberal Peace'”, International Peacekeeping, C. 11, S. 1: $59-81$.

Cunliffe, Philip (2007), "Sovereignty and the Politics of Responsibility", (Ed. Christopher J. Bickerton vd.), Politics without Sovereignty: A Critique of Contemporary International Relations, New York:UCL Press: 39-57.

Deng, Francis M.; Kimaro, Sadikiel; Lyons, Terrence; Rothchild, Donald; Zartman, I. William (2010), Sovereignty as responsibility: conflict management in Africa, Brookings Institution Press.

Donelan, Michael (1990), Elements of International Political Theory, Oxford: Clarendon Press.

Dunford, Robin; Michael Neu (2019), "The Responsibility to Protect in a world of already existing intervention" European Journal of International Relations, C. 25, S. 4: 1080-1102.

Ertuğrul, Ümmühan Elçin (2016), “Koruma Sorumluluğu: İnsani Müdahaleyi Makyajlamak”, Gazi Üniversitesi Hukuk Fakültesi Dergisi, C. 20, N. 2: 441-470.

Evans, Gareth (2016) "R2P: The Next Ten Years”, Oxford Handbook of the Responsibility to Protect, (Ed. Alex Bellamy ve Tim Dunne, Oxford: Oxford University Press: 913-931.

Glanville, Luke (2016), “Does R2P matter? Interpreting the Impact of a Norm”, Cooperation and Conflict, C. 51, S. 2: 184-199.

Global Centre for Responsiblity to Protect, "R2P References in United Nations Security Council Resolutions and Presidential Statements" http://www. globalr2p.org/media/files/unsc-resolutions-and-statements-with-r2p-table-asof-20-june-2018.pdf (Erişim Tarihi 02/04/2019).

Global Centre for Responsiblity to Protect, "UN General Assembly Resolutions Referencing R2P", http://www.globalr2p.org/resources/1133 (Erişim Tarihi 02/04/2019).

Gözen Ercan, Pınar (2014), “R2P: From Slogan to an International Ethical Norm”, Uluslararası ilişskiler, C. 11, s. 43: 3552.

Gözen Ercan, Pinar (2016), Debating the Future of the 'Responsibility to Protect': The Evolution of a Moral Norm, Londra: Springer.

Hehir, Aidan (2013a), "The Permanence of Inconsistency: Libya, the Security Council, and the Responsibility to Protect", International Security, C. 38, S.1: 137-159.

Hehir, Aidan (2013b) "The responsibility to protect as the apotheosis of liberal teleology." (Ed. Aidan Hehir ve Robert Murray), Libya, the responsibility to protect and the future of humanitarian intervention, Londra: Palgrave Macmillan: 34-57.

Hehir, Aidan (2019), Hollow Norms and the Responsibility to Protect, Palgrave Macmillan.

Hindawi, Coralie (2016), "What if R2P Was-Truly-Everyone's Business? Exploring the Individual Responsibility to Protect”, Alternatives, C. 41, S.1: 29-48. 


\section{Eskişehir Osmangazi Üniversitesi iiBF Dergisi}

Hubert, Don (2004), “An Idea that Works in Practice”, Security Dialogue, C. 35, S. 3: 351-352.

Kelleci, Tuğçe; Bodur Ün, Marella (2017), "TWAIL ve Yeni Bir Hâkimiyet Aracı Olarak Koruma Sorumluluğu (R2P): Libya Örneği”, Uluslararası iliş̧kiler, C. 14, S. 56: 89-104.

Kenkel, K. M; Stefan, C. G. (2016), "Brazil and The Responsibility While Protecting Initiative: Norms and The Timing of Diplomatic Support", Global Governance: A Review of Multilateralism and International Organizations, C. 22, S. 1: 41-58.

Linklater, Andrew (1981), "Men and Citizens in International Relations”, Review of International Studies, C. 7, S. 1: 2337.

Manning, Charles A. W. (1962), The Nature of International Society, Londra: Macmillan.

Mayall, James (2013), World Politics: Progress and Its Limits, New York: John Wiley \& Sons.

Mégret, Frédéric (2009), “Beyond The 'Salvation' Paradigm: Responsibility to Protect (Others) vs The Power of Protecting Oneself", Security Dialogue, C. 40, S. 6: 575-595.

Okolo, Ben Simon (2008), "Human Security and The Responsibility to Protect Approach: A Solution to Civilian Insecurity in Darfur", Human Security Journal, C. 7: 46-60.

Paris, Roland (2014), "The 'Responsibility to Protect' and the Structural Problems of Preventive Humanitarian Intervention", International Peacekeeping, C. 21, S. 5: 569-603.

Peltonen, Hannes (2011), "Sovereignty as Responsibility, Responsibility to Protect and International Order: On Responsibility, Communal Crime Prevention and International Law”, Uluslararası Ilişkiler, C. 7, S. 28: 59-81.

Roff, Heather M. (2013), Global Justice, Kant and the Responsibility to Protect: A Provisional Duty, Londra: Routledge.

Schermers, Henry (2002), "Different Aspects of Sovereignty", (Ed. G. Kreijen), State, Sovereignty, and International Governance, Oxford: Oxford University Press: 185-192.

Schouenborg, Laust (2012), The Scandinavian International Society: Primary Institutions and Binding Forces, 1815-2010, Londra: Routledge.

Sue, Henry (1980), Basic Rights, Princeton: Princeton University Press.

Telli, Azime (2012), "Insani Müdahaleden Koruma Sorumluluğuna Geçiş: Eski Sorun, Yeni Kavram”, NEÜ Sosyal Bilimler Enstitüsü Dergisi, C. 1. , S. 2: 206-220.

Thakur, Ramesh (2011), The Responsibility to Protect: Norms, Laws, and The Use Of Force In International Politics, Londra: Routledge.

Thakur, Ramesh (2013), "R2P after Libya and Syria: Engaging Emerging Powers”, The Washington Quarterly, C.36, S. 2: 61-76.

United Nations, "2005 World Summit Outcome Document", A/RES/60/1, https://www.un.org/en/development /desa/population/migration/generalassembly/docs/globalcompact/A_RES_60_1.pdf (Erişim Tarihi 02/04/2019).

United Nations, Secretary-General Report "Implementing the Responsibility to Protect", A/63/677, https://undocs.org/A/63/677 (Erişim Tarihi 02/04/2019).

United Nations, Secretary-General Report, The Responsibility to Protect, Report of the International Commission on Intervention and State Sovereignty, A/57/303. https://undocs.org/A/57/303, (Erişim Tarihi 13/10/2019).

Vincent, R. J. (1995), Human Rights and International Relations, Cambridge: Cambridge University Press.

Waltz, Kenneth (2000), "Structural Realism After the Cold War", International Security, C. 25, S. 1: 5-41.

Watson, Adam (2002), The Evolution of International Society, Londra: Routledge.

Wheeler, Nicholas (2000), Saving Strangers: Humanitarian Intervention in International Society, Oxford: Oxford University Press.

Wheeler, Nicholas J. (2000), Saving Strangers: Humanitarian Intervention in International Society, Oxford: Oxford University Publishing.

Wheeler, Nicholas; Dunne, Tim (1998), "Hedley Bull and the Idea of a Universal Moral Community: Fictional, Primordial or Imagined?", (Ed. Barbara. A. Roberson.), International Society and The Development of International Relations Theory, Londra: Pinter: 43-58.

Wight, Martin (1978), Power Politics, Londra: Continuum.

Wight, Martin (1991), International Theory The Three Traditions, Leicester: Leicester University Press. 


\section{Extended Summary}

\section{Responsibility to Protect: Protecting Humans in a World of States}

This study aims to provide a theoretical contribution to the scholarly debates on Responsibility to Protect (R2P hereafter). R2P is a United Nations (UN) mechanism developed to take necessary measures to stop human rights atrocities. It is initiated specially as a response to human atrocities of 1990 s such as Rwanda and Srebrenica, where international society failed to act or acted reluctantly. This mechanism's main goal is to connect state sovereignty to responsibility. This means a government is capable of legitimately using its sovereignty rights as long as it respects the human rights of people under its authority. If it intends to use its sovereignty rights to violate the human rights of its citizens, it is other states' and international society's responsibility to fulfill the necessary actions to restore the rights of those people. In the light of R2P's definition, this paper's main argument is that in a world of states, in which political domain is largely dominated by sovereign states, mechanisms to protect human beings from harm, violence and inhumane treatment is a quite hard mission. This is partly because dominant political organization type of our time, that is, sovereign states, controls the international realm almost completely, leaving limited room for non-state action as well as non-state norm entrepreneurs. It is true that R2P is an interstate mechanism. It requires state-to-state cooperation together with international society's coordination. Nevertheless, it is based on a value - respect to human rights - that is originally inter-human. For that reason, there is an inherent tension between the normative basis of R2P and its implementation mechanisms. Because world of states, or in other words, international society, functions on the basis of interstate relations and institutions that prioritize state and state originated norms, such as non-intervention and sovereignty. World of humans, or in other words, world society, denies priority of polities over human beings, and accepts that humans are true bearer of rights in the international.

That world society and international society dichotomy is best conceptualized within the English school of international relations. That is the primary reason for adopting this theory to analyze R2P and its possible shortcomings for protecting individuals. The English school scholars, particularly Hedley Bull (1985: 13), defines international society as a group of states being aware of common values and interests, voluntarily being bounded by a common set of rules as well as sharing the work of common institutions. Contrary to international society, world society describes values and interests transcending state domain, and those values and interests are shared by human beings. Individuals and other non-state actors, such as groupings of individuals other than states, can mobilize those values and interests and regulate their relationships with one another to achieve an institutionalized, particular order. Another important tenet of the English School thinking is that together with international system - which identifies non-social type of relationship between states - international society and world society co-exist at any point of world history. One of these types of political organizations of the international realm may be dominant, but the other two never disappears. This theoretical framework best suits the needs of this work since it provides the analytical ground for comparing and contrasting different forms of interaction between states and non-state actors as well as values, norms and rules among them. Applied to contemporary international relations, this theory argues that today, world politics represent an international society where world society and international system are in the shadow. Given this theoretical scheme, R2P is accepted as an element of world society, which is tried to be implemented in international society, requiring the smooth operation of interstate institutions and rules.

This paper then turns its focus on normative and legal foundations of the R2P. A brief narrative of a shift in the understanding of security in world politics indicates that "human security" as a concept and as a policy replaces conventional understandings of security. R2P is a human security policy for being one of the mechanisms of world politics that aims to protect human beings from various types of violence and harms coming from states. On the normative grounds, it accepts that all humans regardless of their physical and ideological differences possess human rights equally, and it is their country's as well as international society's responsibility to respect and protect those rights. So, it is a norm of world society that needs to be followed by states in the international society. On the legal grounds, R2P, as a policy of securing human beings, challenges state sovereignty by definition. Because it ascribes responsibility to states and international society to protect human rights, and in the case of violation of those rights, it requires states and international society to take timely and decisive action. These decisive actions are not devoid of humanitarian intervention or international economic and political sanctions. For this reason, R2P slightly redesigns the legal definition of sovereignty in a way to limit a government's rights over its people. Furthermore, it burdens other states and international society to take action at the expense of human rights violator country's "sovereignty rights".

A brief analysis of the relevant literature and practices of R2P shows that most of the implementations of the mechanism are problematic. This is mostly because R2P requires United Nations Security Council's (UNSC) resolutions to be implemented and the Council takes its decisions on events relevant to this mechanism on a case by case basis. 


\section{Eskişehir Osmangazi Üniversitesi ïiBF Dergisi}

These two main features of the R2P are largely the source of unstandardized implementation of R2P. Because UNSC is an element of international society and acts according to interstate institutions, especially the balance of power and great power management. Being a state club, UNSC favors states and their rights over the rights of human beings. R2P, on the other hand, is an element of world society. As world politics to a large extent is being dominated by international society and its institutions, R2P's success in protecting human beings is quite remittent. A very short study of concrete examples such as Libya, Syria and Yemen empirically proves that point.

This study concludes that the tension between international society and world society is the primary reason for the troubled functioning of R2P. "Every international society acts according to its institutions" (Wight, 1978: 111). As modern international society that we live in is largely dominated by nation sovereign states and institutions functioning among them, it is not surprising to see that it throttles world society's capacity to establish new norms and to change state behavior accordingly. 